\title{
Engaging Math-Avoidant College Students
}

M. Paul Latiolais

Portland State University, hmpl@pdx.edu

Wendi Laurence

Create-osity, teach4always@yahoo.com

Follow this and additional works at: https://digitalcommons.usf.edu/numeracy

Part of the Mathematics Commons, and the Science and Mathematics Education Commons

\section{Recommended Citation}

Latiolais, M. Paul, and Wendi Laurence. "Engaging Math-Avoidant College Students." Numeracy 2, Iss. 2 (2009): Article 5. DOI: http://dx.doi.org/10.5038/1936-4660.2.2.5 


\title{
Engaging Math-Avoidant College Students
}

\begin{abstract}
This paper is an informal, personal account of how we, as two college teachers, became interested in math anxiety, decided to explore it amongst students at our institution in order to inform our teaching, and became convinced that the massive problem is math avoidance. We tried discussion groups, but few students attended, although those that did made useful suggestions. Thus informed, we designed an innovative course, Confronting College Mathematics as a Humanities course with the possibility of credit toward the math requirement, but it was undersubscribed in its first offering and had to be canceled. How can we get college students who avoid math to break through the barrier of math avoidance? We have now begun to explore a new approach: Second Life, where students can engage math-and quantitative literacy-virtually, and anonymously.
\end{abstract}

Keywords

Math, Anxiety, Avoidance, requirements, numeracy, quantitative literacy

Creative Commons License

(c) (1) (9)

This work is licensed under a Creative Commons Attribution-Noncommercial 4.0 License

This perspective is available in Numeracy: https://digitalcommons.usf.edu/numeracy/vol2/iss2/art5 


\section{Introduction}

Helping students acquire the quantitative literacy to support their career aspirations is a goal across the continuum of K-20 education. This paper discusses a quantitative literacy obstacle that may be prevalent at the college level-math avoidance. As we author this paper, we hold the stance of two teachers who would like to improve our practice. As a result, we tell the story of how one student's regrets about not acquiring quantitative skills appropriate to her major led us to explore math anxiety in college students. Our account retraces our conversations and our attempts to understand math anxiety and how it affects our students. We look back to re-trace questions, discoveries and conversations that led us to the inescapable conclusion that we were considering the wrong phenomenon. The patterns we saw led us to re-examine our assumptions and our questions. Thus our story tells how we came to the eventual and what we consider the essential question: How might we engage math-avoidant students? We hope by recounting our journey, we will call attention to our personal conclusion that math avoidance is a central issue for many undergraduate students. While we have not yet in our own minds found an answer to the question of how to engage math-avoidant students, we provide a discussion of some of the challenges we encountered and suggest an idea that we think might help math-avoidant students choose to engage in learning mathematics.

We all have met individual students who have conquered their mathematical issues and have gone on to bachelors, masters and even Ph.D. degrees in mathematics. Other students tell how their career choices have expanded because they took, survived and understood calculus. These inspiring stories tell us about the possibility of success in the face of previous defeat, yet they also leave us wondering how to open avenues of possibility for more students. A college student's decision to avoid mathematics can have an unfortunate impact, especially when not taking mathematics becomes a limiting factor in the understanding of math in their lives or in their choice of major and career. At some institutions, including Portland State University (PSU) where our story took place, a lack of mathematical literacy prevents some students from earning an undergraduate degree.

\section{The beginning: A student's simple statement of regret}

It was at the 2001 Fall "Focus on Faculty" day at PSU when the question of how we might open more opportunities for students to learn mathematics first arose in our minds. Our keynote speaker for the day was Professor Richard Light, author of Making the Most of College (Light, 2001). Part of Dr. Light's presentation was a public interview of a panel of PSU students. Towards the end of his 
presentation, Professor Light asked the panel if there was anything they had wanted to learn but had not. One senior economics major spoke of her regret that she had not taken the math classes she felt she needed. She wanted to take more math, but she would not take it in a math department.

That young woman's story haunted both of us for two years-Paul from the point of view of a mathematician and Wendi from the point of view of access to learning and developing support networks. As two teachers, we kept having conversations that raised questions such as: What math did she think she needed? Why did she not want to take it from the math department? Most importantly, how would she find a course that served her needs? These questions gave us the impetus to review the literature, think of some research questions, and begin to plan an informal study that would allow us to investigate this phenomenon for the benefit of our teaching.

What we found was that there is considerable literature on what might support math-anxious students once they have entered a math classroom (e.g., Tobias 1994). However, we didn't find articles that investigated what factors encourage students who actually avoid math to break through the barriers they perceive and decide to engage in learning math. As a result, our initial question took the form of: How can we help undergraduate students with math anxiety develop the confidence and ability to learn the mathematics they need to succeed in the careers they would like to pursue? Our initial question followed a convoluted path of change as it was combined with our emerging experiences of trying to create a course for students while we conducted our study. Eventually, our various experiences led us to our conclusion that it was not just a matter of anxiety about math but an ingrained pattern of beliefs that led to the avoidance of all things mathematical.

\section{Our paper: An intertwining of methodology and narrative}

To describe our study without weaving in our experiences of trying to create a course would leave out the lived experiences and hallway interactions with other faculty that informed our thinking and eventually led to a possible solution that did not exist when we first looked at these questions. It became a lived experience of Rilke's admonition to live the question and then one day you will live your way into the answer (Rilke, 1934).

\section{Initial Investigations}

Initially, we began in the Fall of 2002 to investigate the question as part of the President's Assessment Initiative at PSU. We refined our initial set of questions through discussions with a pilot group of six graduate students from a variety of 
non-mathematical programs identified through personal connections. These students helped us see that motivation for attending a math class would need to be personal. Students would need support working through their past experiences so that they could learn. Also, knowing about the classroom environment ahead of time would make a difference in their choice to enroll. They pointed out that their ability to interact with the instructor would be a key factor in their choice of taking the class, choosing to ask questions out of class, and participating in class. They emphasized that statements such as "What don't you understand about this problem?" could lead them to question their own ability to understand math. They specifically pointed to questions such as these as moments where they shut down and chose not to engage. They alluded to the idea that if they understood what they did not understand then they would not be struggling with the question.

Concurrently, Wendi also worked with Paul as he taught calculus that year and investigated his interaction with students. That interaction changed when he changed his methods of assigning homework due to a conversation we had with a colleague. Paul had observed a hesitation in the students' question asking. We discussed those observations with Professor Dalton Miller-Jones, a colleague from the psychology department. Dalton suggested asking students to come back with their questions not their answers. This was a real shift for Paul, and it made a difference. Oftentimes, we give math students homework that many of them cannot complete without outside assistance. Offering those students a chance to deal with their mathematical challenges in the class after identifying those challenges as homework caused a major shift in the classroom climate.

Paul also integrated using an electronic bulletin board to allow students to ask questions in a different format. Rather than having the students turn in their questions on sheets of paper, he asked them to submit them to a bulletin board that all students had access to. He told students that if they answered other students' questions, that would count as one of their questions. Students began answering each other's questions and engaging in mathematics discussions online. This experience provided two shifts in our thinking. The first shift was in the use of questions to draw out students versus a pattern of asking them for answers to gain their participation. Second, in hindsight, the possible role of an online experience was beginning to emerge.

Next, we invited a number of undergraduates to group discussions. The first few times we tried to convene a group, the students agreed to attend and then did not show up. Eventually, we increased the remuneration, by adding pizza, and we recruited participants from specific required basic math courses where students were engaged in a math class required for graduation but had reservations about math or previous negative experiences. As a result, we were able to recruit for and conduct one discussion group of eight students. As we look back, we believe our first evidence of math avoidance was our failure to convene the first discussion 
groups. The degree of hesitation and avoidance of anything to do with math was telling us to pay attention to what support the students needed just to choose to engage. The degree of avoidance behaviors these students exhibited began to point to a well-honed ability to work around anything to do with math.

\section{Group Discussions : Math Through Students' Eyes}

We both went into our discussions with the six graduate students and then the eight undergraduates with some assumptions of our own on what math difficulties students would have from the perspectives of our training in our two different disciplines. We also realized that each of us had struggled with certain aspects of learning mathematics and tried to be transparent about them. Paul spoke of trouble with initial rote memorization of multiplication tables in elementary school. Wendi took math in college; however, she struggled with bad handwriting and number reversals and was done with math as soon as she had fulfilled the college requirements for graduation. Our participants expanded on our experiences. The discussions revealed that these students felt they needed trust and communication, a way to bridge gaps in their math, a classroom that doesn't scream math class, and a way to directly experience and apply the learning of math to their interests.

\section{Strong need for trust and communication}

The first pattern of supports that persuaded the students to engage in a math class was a strict college math requirement for graduation. They were specific in mentioning a college graduation requirement versus a major requirement. This line of questioning was the first time we began to track the pattern of avoiding math and anything associated with it. While we reviewed the group discussions, we noted a tendency amongst the students that a global math requirement for graduation brought them to a math class, whereas a department requirement for a major brought avoidance.

Once the students had entered a math class, they felt a strong need for trust and communication. Teachers' ability to explain, their openness to answering questions, and their communication styles and patience were all consistently listed as essential for the students to continue in mathematics. In particular, the students pointed to a teacher's openness to finding "something to explain it to me different." By different they were referring to the ability to explain it in such a way that the mathematical principles they were examining made sense and provided everyday examples_- "not just telling me to do something." The students also mentioned they sometimes felt they needed to be able to learn in a sequence different than those of their other classmates. 


\section{A place where they can backfill}

The students' stories were eerily similar. Each student identified a time and place where they "got stuck", and usually an individual who either told them or implied that the student had inadequate mathematical capabilities. These skill sets that "didn't click" kept them from going forward. When asked when they started having trouble with math, students responded:

"I couldn't figure it out...long division."

"Times tables."

"I don't remember why...I was scared."

"Geometry in high school."

"Realizing the teacher is doing something different than my brain processed."

These experiences seemed to be at the core of their math anxiety and their beginnings of math avoidance. Many came to the conclusion that some students were good at math and some weren't, and they had been put into the latter group.

\section{Making a connection}

When we asked if there was anything that would help them learn math better they had situational connections and content suggestions. Situationally, the classes would need to look different than a math class, or they would need to use different manipulatives than mathematicians think about or use. The students want to know how people really use this math, and how it applies to life. To connect with these math-avoidant students they suggested content problem solving such as sewing, art, real estate, business, cashier at work, writing music - a suggestion that aligns with the quantitative literacy literature (e.g., Steen, 2001).

One student wanted to remind the teachers that for them "math is a completely different thinking process than anything else I think about." One student suggested a "situation where professor could teach at my rate of learning." Another student wanted instruction on "How to write it," and a chance to practice: "Once I figure it out a chance to do it once, again and again."

\section{A Course of Course}

Based on what we found in our discussions with students, we designed a course, which was offered in the summer of 2007. Billed as a math "boot camp," the course was proposed and approved as a Humanities 100-level course, Conquering College Mathematics. The course description read as follows:

Students will learn how to deal with mathematical issues, developing 
coping strategies while doing college level mathematics. The goal of the course will be the development of skills needed to succeed in the math in the majors the students will pursue. The course focus will be on problemsolving. 4 credits. (The course is expected to meet general math requirement.)

We offered the course in an intense one-week format in September before the fall quarter began. The idea was that students would meet with the class from 9 am to $12 \mathrm{pm}$ and from 2 to $4 \mathrm{pm}$. We intentionally chose these times to allow for student access to each other and the instructors during an allocated homework time from noon until $2 \mathrm{pm}$.

There are three elements of the course description that we thought were particularly relevant to students. We thought it was important to offer potential math credit for the course, hence making it one of the courses a student could take to meet the university's math requirement. The math credit, however, was difficult to support, because we did not guarantee specific math content. We explained to administrators and advisors that it would be up to the instructors to propose that a student get credit, if in the instructor's opinion the student had "done enough." While this would involve detailed assessment above and beyond that of a typical course, we felt it would be a worthwhile investment in a student's future.

Second, the course scheduling was thought to allow students to take the "boot camp" course just prior to starting the fall term. We thought that this timing might be another draw for students. In that we were wrong. The schedule, we were told, interfered with some students' work. A less intense time frame might have allowed students to work around the course better.

Finally, Conquering College Mathematics was not labeled as a "math" course but as a "humanities" course. We hoped this might offer a bridge to students who were avoiding math courses.

Wendi and Paul designed learning experiences where students could engage in problem solving using mathematics but where the focus would be on the content area that held their interest. Reflective conversations and focus groups would then be used as a part of the course to bring out questions from the students and challenge their belief that they cannot do mathematics. We would use books that, we hoped, would resonate and help the students progress. One was to fill in prior math knowledge. Another, a psychology book, was to explore the patterns of beliefs we hold. A third, the children's fantasy The Number Devil, was to bring a lighter side to the "math is boring" issue (Enzensberger, 1998).

Unfortunately, Conquering College Mathematics attracted only three students, not enough for Summer Session to offer it.

Reflecting on our failed course, we realized that a course was not an "of course" but merely the format we as educators were used to delivering learning. 
So now what? Try again with changes? Perhaps.

Or maybe there is another way, another format to engage math-avoidant college students.

\section{Another Student's Story}

Meanwhile, Paul had a different kind of encounter with a student-a student who did not want to avoid math. Quite to the contrary, this student was looking for access points.

On his way to a conference, Paul noticed his shoes were a bit bedraggled, but he had time to get them polished at the airport. The young woman who shined his shoes quickly discovered that he was a math professor and mentioned that she was in community college working her way toward a degree in chemistry. She asked where she could go on the Web or in a book to find the specific math she needed for the chemistry she wanted to learn. Paul then began thinking about how to create online mathematical access points from the perspective of the specific disciplines that interested a student. A large motivating factor was his realization that even though we had focused on helping students engage in math, he had no suggestions of math access points to direct her to.

\section{And Now Something Completely Different}

During the summer of 2007, Paul was introduced to Second Life (SL) as a possible alternative format for delivering mathematics content. $S L$ is a 3-dimensional virtual reality environment ${ }^{1}$ that seems to have resonated with a lot of people, including educators. $^{2} \quad$ At first glance, a 3-D virtual world might seem an odd place to study math anxiety and math avoidance. There is something about a virtual world that captures human interaction and draws people closer than a Web page or e-mail or even teleconferencing (Uskala 2009). Shy, "avoidant" students may find the environment especially appealing. ${ }^{3}$

While our Conquering College Mathematics was in the process of scaring students away, Paul and Sylvia Giroux, a colleague at PSU, began exploring SL

\footnotetext{
${ }^{1} \mathrm{http}: / /$ secondlife.com/whatis/

${ }^{2}$ http://secondlifegrid.net/slfe/education-use-virtual-world

${ }_{3}^{3}$ Consider these student comments from Sanchez (2008): (1) "One thing I noticed about holding class in Second Life was that more than the usual people participated in the discussions that we have. It seems that the barrier of shyness or being uncomfortable about expressing one's opinion was just taken away...." (2) "... I feel like I can open up and contribute more when I'm not in an actual classroom i think it's because i'm shy in public. Having conversations through the computer is what our generation does though so I feel more comfortable that way."
} 
and interviewing avatars about their mathematics issues. The response to a "math" presence in $S L$ was extremely positive. Avatars who self-identified as math phobic actually sought us out to talk about their issues. This was a completely different experience than Paul and Wendi had in "Real Life."

In the $S L$ context, the question became: How do we systematically encourage mathematical conversations in $S L$ ? We wanted to know both what people need and how to meet identified needs? We did not want to start with a course, although some high schools and colleges are currently offering online courses or parts of courses through $S L$. The potential of offering math content in an interactive virtual environment is appealing to a mathematician, but are those the resources that students feel they need? What is it that will attract a math-avoidant student to engage in the first place? And what about resources for students more interested in mathematical connections than the theoretical constructs? Could we address the quantitative literacy needs of a chemistry major, for example? There are a lot of questions to ask and virtual experiments to try before thinking of possibly designing yet another course which students could avoid.

In order to study what the potential interest and issues are in the $S L$ audience, we decided to create an environment in which people could, and are encouraged to "talk" about mathematics among themselves and see what they talk about and what the "math talk" technical issues might be. Paul and Sylvia set up a "math tutoring" environment, much like what you would see in any college math department in the country, but this one is in the virtual world. We plan to set times at which tutors will be available for questions. The space we created is big enough that avatars who want to "talk math" can communicate with the tutors, or each other. Paul is currently investigating the research parameters that will be necessary in this new and complex environment. He is finding new ways to document and analyze the discussions that take place. Sylvia is recruiting the tutors from other segments of the $S L$ community. An initial attempt to use traditional on-demand math tutors as a component of their responsibilities did not work. The "real world" students were too demanding to allow the tutors to spend time with $S L$ students.

\section{Concluding Remarks}

We have come to believe that, for undergraduate students, it is not simply about anxiety or dislike for mathematics but an ingrained pattern of avoidance coupled with a belief that they cannot do math because they can never gain the skills they should have had years ago. We are currently working on the premise that students need a bridge that presents math in a way that they can choose to engage in a lowstakes situation in a way that interests them. But, how do we find these students? How many of them are there? How do we let the students know about access 
points that they would be less inclined to avoid?

Discussing our questions with students gave us some ideas on how to engage those students, but we are still struggling with how to get students' attention in the first place. As we mentioned, a university requirement does force them to show up, but that leads to other problems. The standard entry-level college math course, including the typical quantitative literacy course such as PSU's Excursions in Math course (textbook: Tannenbaum 2006) requires facility with high school-level algebra. Students who wait until their senior year (42\% of the Excursions in Math class at PSU in 2007/08) now have had a longer time to forget what they did learn in high school. Is it appropriate at this point to require these students to take a placement test and force them to pay extra for developmental courses to gain or regain the needed algebraic skills? Can we identify these students earlier in their college career? If we can identify them, using both placement test data along with a math anxiety survey (e.g., Alexander and Martray, 1989), how do we engage them? Again a placement test on college entry might be appropriate, but it is more than a lack of skills that is the problem. It would seem that involvement of counselors would be necessary as well as targeted courses designed and taught by specially trained faculty.

Second Life seems one promising approach at this point at least for those students who are not avoiding technology as well. Because $S L$ reaches many students, we feel it may offer a low-stakes situation where students can ask questions, even remedial ones, and begin to recognize that they can successfully engage in mathematics.

\section{References}

Alexander, L., and C. Martray. 1989. The development of an abbreviated version of the Mathematics Anxiety Rating Scale. Measurement and Evaluation in Counseling and Development 22: 143-150.

Eisenhart, M. 2000. New directions and approaches to culture, learning, and education. In Schooling the Symbolic Animal: Social and Cultural Dimensions of Education, ed. B. Levinson et al. Lanham, MD: Roman and Littlefield.

Enzensberger, Hans Magnus. 1998. The Number Devil: A Mathematical Adventure. New York: Henry Holt.

Light, Richard J. 2001. Making the Most of College: Students Speak their Minds. Cambridge, MA: Harvard University Press.

Rilke, R.M. 1934. Letters to a Young Poet. (M.D. Herter Norton Trans.) New York: Norton.

Steen, Lynn Arthur, ed. 2001. Mathematics and Democracy: The case for Quantitative Literacy. Washington, DC: Woodrow Wilson National 
Fellowship Foundation. http://www.maa.org/q1/mathanddemocracy.html (accessed May 25 2009).

Sanchez, Joe. 29 January 2008. Teaching with voice issues. In The Educators Coop, Joe Sanchez and Leslie Jarmon. http://educatorscoop.org/blog/?p=34 (accessed June 21 2009).

Tannenbaum, Peter. 2006. Excursions in Modern Mathematics, $6^{\text {th }}$ Edition, Cranbury NJ: Pearson/Prentice Hall.

Tobias, S. 1994. Overcoming Math Anxiety. New York: Norton.

Uskala, (2009, January 12). What's the Point? Video posted to http://www.youtube.com/watch?v=AalMTTQKx4g (accessed May 25 2009). 